\title{
POEZJA RELIGIJNA W KRĘGU MNICHÓW ZAKONU GROBU BOŻEGO W POLSCE - GEMMAE SACROSANCTAE CRUCIS JAKUBA PAWŁA RADLIŃSKIEGO
}

W 1. poł. XVIII wieku w Zakonie Bożogrobców w Miechowie rozpoczął się czas reform i starań o przywrócenie Zgromadzeniu dawnej, a w mijającym stuleciu nieco przyćmionej, świetności ${ }^{1}$. W latach 1744-1765 prepozytem generalnym Zakonu był Jakub Paweł Radliński (ca 1684-1762), który w młodości uczył się w kolegium jezuickim, potem studiował w Krakowie filozofię i teologię, a swą naukę zakończył stopniem doktora teologii². Radliński był również historykiem Zakonu i płodnym pisarzem. Pisał zarówno poetyckie utwory okolicznościowe i religijne, jak i dzieła z zakresu teologii. Był autorem kilku pism o Grobie Bożym. Radliński przez wiele lat prowadził też kronikę parafii, a potem kronikę klasztoru miechowskiego. O jego erudycji, a zarazem silnych związkach z klasztorem, świadczy opracowanie łacińskich sentencji, które funkcjonowały jako inskrypcje zdobiące bibliotekę miechowską. Upodobanie do łączenia słowa $\mathrm{z}$ formą architektoniczną czy plastyczną znajduje wyraz także w dziełach literackich Radlińskiego. Jedną z jego obszerniejszych, bo liczących ponad 200 stron, książek było wydane w $1748 \mathrm{r}$. w Krakowie w liczbie 800 egzemplarzy dzieło Corona urbis et orbis, zawierające inskrypcje i wiersze poświęcone warszawskiej Bibliotece Załuskich33. Podobną epizodyczną strukturę mają też inne zbiory autorstwa Radlińskiego. Poniżej zostanie omówiony jeden z nich.

Dzieło zatytułowane Gemmae Sacrosanctae Crucis Domini Nostri Jesu Christi (Klejnoty Najświętszego Krzyża Pana Naszego Jezusa Chrystusa) jest

* Prof. dr hab. Barbara Milewska-Waźbińska - profesor zwyczajny w Zakładzie Studiów nad Renesansem w Instytucie Filologii Klasycznej na Wydziale Polonistyki Uniwersytetu Warszawskiego; e-mail: wazbinska@uw.edu.pl.

${ }^{1}$ Por. Z. Pęckowski, Bożogrobcy w Polsce, EK II 879-881.

${ }^{2}$ Por. R. Skrzyniarz, Radliński Jakub Pawet, EK XVI 1092-1093; J. Kozłowski, Radliński Jakub Pawet, PSB XXIX 708.

${ }^{3}$ Por. B. Milewska-Waźbińska, „Corona urbis et orbis” Jakuba Pawła Radlińskiego. Uwagi o poetyckim pomniku wystawionym Bibliotece Zatuskich, „Rocznik Biblioteki Narodowej” 33-34 (2001) 57-66. 
mało znane i do tej pory nieopracowane ${ }^{4}$. Książka wydana została w $1755 \mathrm{r}$. w Krakowie w oficynie typografa królewskiego Michała Dyaszewskiego. Na odwrocie strony tytułowej w ozdobny fryz roślinny wpisano epigramat. Dyaszewski ozdabiał $\mathrm{w}$ ten sposób także inne wydawane przez siebie książki - ten sam fryz pojawia się np. na stronie tytułowej dzieła Radlińskiego zatytułowanego Fundamenta scientiarum, seu principia et axiomata, partim philosophica, partim theologica wydanego w 1753 roku.

Wspomniany epigramat rozpoczynający Gemmae Sacrosanctae Crucis zawiera trzy dystychy elegijne i poprzedzony jest mottem zaczerpniętym z listu św. Pawła do Galatów (Ga 6, 14): „Mihi autem absit gloriari, nisi in Cruce Domini Nostri IESV ${ }^{5}$ Christi, per quem mihi mundus Crucifixus est et ego mundo"6. Epigramat stanowi wierszowany komentarz do tego listu:

„Quod Crucis ignitus dicebat PAULUS amator,

Haec ego cum PAULO profero, corde sono:

Absit ab ore meo vesani gloria mundi!

Crux JESU Christi, gloria tota mei!

Perque Crucem mundus, mihi Crucifxus in aevum!

Et per Eam mundo, sim Crucifixus ego"7.

Cały tekst zamieszczony na odwrocie strony tytułowej, składający się z cytatu biblijnego i z epigramatu pełniącego funkcję wierszowanego komentarza, stanowi rozbudowane motto do dzieła, w którym autor będzie oddawać cześć Świętemu Krzyżowi. Temat ten bez wątpienia bliski był Radlińskiemu, gdyż sam jako członek Zgromadzenia nosił oznakę religijną w formie krzyża. Warto dodać, że wspomniana rozbudowana postać motta, na którą składa się cytat i epigramat, przypomina konstrukcję stemmatyczną, często w tym właśnie miejscu umieszczaną w ramie wydawniczej druków staropolskich ${ }^{8}$. Stemmat, czyli wiersz na herb, zawierał wprawdzie zazwyczaj rysunek godła, ale istniały też kompozycje heraldyczne ryciny pozbawione. Wiersz nawiązujący do

\footnotetext{
${ }^{4}$ Por. K. Estreicher, Bibliografia polska, t. 26, Kraków 1915, 32-33.

${ }^{5} \mathrm{~W}$ cytatach łacińskich zachowano pisownię starodruku.

${ }^{6}$ Ze względu na czas powstania dzieła, cytaty biblijne podano w przekładzie staropolskim, a nie współczesnym. W thumaczeniu Jakuba Wujka wers ten brzmi: „A ja, nie daj Boże, abym się chlubić miał, jedno w krzyżu Pana naszego Jezusa Chrystusa, przez którego mnie świat jest mi ukrzyżowan, a ja światu”. Tekst za: Biblia w przekładzie księdza Jakuba Wujka z 1599 r. Transkrypcja typu „B” oryginalnego tekstu z XVI w. i wstępy ks. J. Frankowski, Warszawa 1999, 2284-2285.

${ }^{7}$ „Co Paweł gorliwie miłujący Krzyż mówił,

To ja z Pawłem z serca głoszę:

Niech na ustach moich nie będzie chluby szalonego świata!

Krzyż Jezusa Chrystusa całą mą chlubą!

Przez Krzyż świat niech zostanie ukrzyżowany dla mnie na wieki!

I przez Ten niech ja będę dla świata ukrzyżowany”, tłum. własne.

${ }^{8}$ Por. najnowsze opracowanie na ten temat: B. Czarski, Stemmaty w staropolskich ksiażkach, czyli rzecz o poezji heraldycznej, Warszawa 2012.
} 
wizerunku herbowego opiewanej osoby, miasta, czy instytucji, był czasami wzbogacany o motto, czyli sentencję właściwą emblematom ${ }^{9}$. W książce Radlińskiego nie ma, jak wyżej wspomniano, spodziewanej ryciny, ale mowa jest o znaku Chrystusa, czyli o Krzyżu, który jest godłem Bożogrobców. Omawiany epigramat przybiera zatem postać stemmatu na znak Krzyża.

Rozważania na temat domyślnych motywów ikonograficznych w kontekście omawianego utworu mają o tyle sens, że w pełnym tytule dzieła ${ }^{10} \mathrm{i}$ w dalszej treści pojawia się słowo „figura”, które kieruje czytelnika w stronę symbolicznej interpretacji materii biblijnej opisywanej przez autora.

Na karcie A2 książki Radlińskiego znajduje się wiersz dedykacyjny (carmen dedicatorium) pisany w dystychach elegijnych, który nie jest jednak skierowany do żyjącego dostojnika, jak to ma miejsce w dawnych publikacjach, ale do Chrystusa. Autor nawiązuje w swym utworze najpierw do pism św. Tomasza, stwierdzając, że nagrodą dla Akwinaty był sam Jezus. Radliński, zgodnie z toposem afektowanej skromności mówi, że jego dzieło nie jest godne chwały Chrystusa, że nie ma w nim wielu mądrości i błyskotliwych sformułowań, ale że z całego serca dedykowane jest Panu. Oświadczając dalej, że nie oczekuje żadnej wymiernej nagrody poza samym Chrystusem, pisze (k. A2): „Tu mea sis merces, meta, Corona, Salus”"11. Warto zwrócić uwagę na te słowa, gdyż zwyczajowo celem utworów dedykacyjnych, którymi dawni autorzy poprzedzali główny tekst, było oczekiwane wsparcie ze strony osób, do których kierowano wstępy.

Drugi utwór dedykacyjny znajdujący się na kartach A2v-A4 omawianej książki, autor przypisuje Matce Boskiej - Królowej zarówno Nieba, Ziemi, jak i Polski. Wiersz składa się z trzech części. Pierwszy fragment poświęcony jest arcybiskupowi Maciejowi Łubieńskiemu herbu Pomian, który zanim został prymasem, był w latach 1617-1627 generałem miechowskich Bożogrobców, a także autorem Constitutiones Capitulorum generalium Miechoviensium ordinis canonicorum Regularium. Radliński wspomina zasługi generała Łubieńskiego dla klasztoru miechowskiego, mówi między innymi o powiększeniu przez niego biblioteki. Pamięta też o zasługach prymasa dla klasztoru Jasnogórskiego, na przykład o fundacji kaplicy Matki Boskiej. Radliński stwierdza, że on sam nie jest w stanie wznieść podobnej świątyni, ale chciałby zadedykować Maryi swój utwór o Świętym Krzyżu, czyli tytułowe klejnoty (Gemmae). W tej części dedykacji autor wspomina opłakiwanego przez Matkę Syna ukrzyżowanego i stwierdza, że skoro Krzyż był miłością Maryi, to on powierza Jej swoją książeczkę o Krzyżu.

\footnotetext{
${ }^{9}$ Por. tenże, Lemmata $w$ staropolskich konstrukcjach stemmatycznych jako przejaw hybrydyzacji gatunkowej, „Terminus” 14 (2012) 157-178.

${ }^{10}$ Pełny tytuł dzieła Radlińskiego brzmi: Gemmae Sacrosanctae Crucis, Domini Nostri Jesu Christi, ex amplissimo Sacrae Scripturae mari collectae, seu Figurae, et Prophetiae, de Eadem S. Cruce, et Innocentissima Passione ex Libris Veteris et Novi Testamenti, desumptae, sermone ligato descriptae.

${ }^{11}$ „Ty jesteś moją nagrodą, celem, Uwieńczeniem, Zbawieniem”, tłum. własne.
} 
Drugi wiersz w tej części utworu dedykacyjnego poświęcony jest Obrazowi Matki Boskiej, który czci nie tylko Częstochowa, lecz także cała Polska i inne królestwa. Trzeci utwór już w swym tytule odnosi się do Niepokalanego Poczęcia (Pro Immaculata Conceptione Beatissimae Virginis Mariae). Tekst ten opatrzony został mottem z psalmu 88 według numeracji Wulgaty w wersji: „Quis est homo, qui vivet et non videbit mortem, eruet animam suam de manu inferi?"'12 (Ps 88[89], 49). W pierwszych słowach wiersza zawarta jest refleksja o marności życia ziemskiego i słabości ciała człowieka. Autor odnosi się następnie do postaci Maryi, która, choć obdarzona śmiertelnym ciałem, miała niepodległą śmierci duszę. Nieskalana grzechem pierworodnym tak, jak inni śmiertelnicy, lśni czystym blaskiem. Utwór kończy następujący dystych:

„Hanc animae mortem, quae nescis tota MARIA,

Et mea mens, labis nesciat arte mori”'13.

W słowach tych dostrzec można aluzję do pradawnej modlitwy rozpoczynającej się od słów:

„Tota pulchra es, Maria.

Et macula originalis non est in te".

Fragment nawiązuje jednocześnie do Pieśni nad pieśniami, gdzie w rozdziale 4,7 czytamy: „Tota pulchra es, sponsa mea, et macula non est in te"14.

Kolejnym elementem należącym do ramy wydawniczej książki Radlińskiego, wprowadzonym zaraz po wyrażeniu zgody na druk (,,approbatio ordinaria"), jest umieszczona na kartach B-B2v przedmowa do łaskawego czytelnika („Praefatio ad benevolum Lectorem”). Autor wyjaśnia w niej genezę swego dzieła, wspominając dwa symbole zakonu Bożogrobców. Pierwszym z nich jest Święty Krzyż, drugim Grób Pański. Radliński dochodzi do wniosku, że skoro o tym drugim opublikował już cztery dzieła, to swą nową książkę pragnie poświęcić Krzyżowi. W dalszych partiach przedmowy uzasadnia podjęcie tej tematyki. Po pierwsze przypomina, że to jego Zakon jako pierwszy zaczął nosić na płaszczu znak Krzyża, opowiada dalej, że Bożogrobcy opiekowali się grobem Chrystusa i drzewem Krzyża Świętego, czyli największymi relikwiami chrześcijan. Drzewo Krzyża towarzyszyło krzyżowcom podczas wypraw do Ziemi Świętej w obronie Grobu Pańskiego. Mówi, że zakonnicy przez 900 lat strzegli Krzyża Chrystusowego. Przypomina następnie, że zakon ustanowił święta ku czci Krzyża. Stwierdza dalej, że to św. Helena matka zarówno Konstantyna Wielkiego, jak i Zakonu, powierzyła Bożogrobcom opiekę nad

${ }^{12} \mathrm{~W}$ przekładzie Jakuba Wujka: „Któryż jest człowiek, który żyć będzie, a nie ogląda śmierci, wyrwie duszę swą z ręki piekielnej?”, por. Biblia w przektadzie księdza Jakuba Wujka, s. 1130.

13 „Tej śmierci duszy, jak cała nie znasz Maryjo,

I moja myśl, niech nie zazna klęski śmierci”, tłum. własne.

${ }^{14} \mathrm{~W}$ przekładzie Jakuba Wujka: „Wszytka jesteś piękna, przyjaciółko moja, a nie masz w tobie zmazy". Tekst za: Biblia w przekładzie księdza Jakuba Wujka, s. 1294. 
Krzyżem. Przypomina też, że Zakonowi podlegają liczne kościoły pod wezwaniem św. Krzyża. Zaznacza, że w kościele w Miechowie przechowywane są dwa fragmenty drzewa św. Krzyża. Skoro istnieje aż tyle powodów - konkluduje Radliński - aby uczcić Krzyż, to wydaje się oczywiste, że i on postanowił napisać dzieło na ten temat. Autor tłumaczy, że dla wyrażenia większej chwały Krzyża opracował wybrane cytaty z Pisma Świętego, dzieł patrystycznych i teologicznych w mowie wiązanej. Na zakończenie Radliński przedstawia strukturę swej pracy i wyróżnia jej dwie części. W pierwszej opracował tematy i symbole zaczerpnięte z Pisma, najpierw ze Starego, potem z Nowego Testamentu, w drugiej zajmuje się przepowiedniami na temat św. Krzyża.

W pierwszej części książki zawarto w sumie 84 epigramaty napisane w dystychach elegijnych, przy czym 77 wierszy dotyczy Starego Testamentu, a 7 Nowego. Każdy wiersz nazwany „figurą" poprzedza tytuł odnoszący się do symbolu biblijnego, np. „Lignum Vitae et Scientiae”, „Flammeus gladius atque versatilis” czy „Baculus Jacob.” Po tytule następują cytaty z Biblii oraz przywoływani są autorzy, którzy wypowiadali się na temat danego symbolu. Zamykający kompozycję epigramat, liczący od kilku do kilkunastu dystychów, stanowi odautorski komentarz.

W drugiej części książki znajduje się 49 utworów nazwanych „Prophetiae”. Autor nie opatrzył tym razem epigramatów tytułowym mottem, ale jedynie obszernymi cytatami i komentarzami. Całość dzieła wieńczy osobny utwór, zawierający dwa epigramaty i zatytułowany Carmen pro Immaculata Conceptione. Obydwa wiersze zawierają po cztery dystychy i opatrzone są mottem. Pierwsze motto zaczerpnięto z psalmu 131, drugie z Księgi Mądrości. Na zakończenie czytelnik ma możliwość zapoznania się z wyrażoną przez autora deklaracją wiary (,Protestatio authoris”) i z epigramatem zatytułowanym Finis:

"In folio finis Crucis est, vel meta loquendi,

Finis at in nullis cordibus, esto Crucis!"'15

Na końcu jako kolejny element zamykający ramę wydawniczą wydawca dodał jeszcze cykl epigramatów chwalących samo dzieło i jego autora. Twórcą tego cyklu był Mateusz Bujdecki. Ciekawe są zawarte na stronach 167-168 refleksje metaliterackie zakończone epigramatyczną pointą:

"Omnia iura Crucis scribit sermone ligato,

Author et eximio carmine quaeque notat.

Cur oratorum verbis linguaque soluta

Non usus? Fluido rhetoricoque stylo?

Crux Christo Christusque Cruci fuit ante ligatus,

De cruce nonne decet verba ligata loqui?"16

${ }^{15}$ „Na karcie jest zakończenie Krzyża, czyli koniec wypowiedzi, ale w żadnym sercu niech Krzyż nie zazna kresu”, tłum. własne.

${ }^{16}$ „O wszystkich zasadach Krzyża autor pisze mową wiązaną i ukazuje je we wspaniałej pieśni. 
Ostatni epigramat z tego cyklu nosi tytuł Votum Authori. Pojawia się w nim życzenie skierowane do autora, aby klejnot Krzyża (,gemma Crucis”) zawsze go zdobił, a w chwili śmierci był pomocą i poprowadził do gwiazd przez bramy Jeruzalem Niebieskiej. Książka Gemmae Sacrosanctae Crucis zaopatrzona jest na końcu w spis treści oraz w erratę.

Omawiane dzieło wyrasta z obowiązującej w pierwszej połowie XVIII wieku praktyki literackiej. Należy przypomnieć, że w epoce, w której żył i tworzył jego autor, teksty łacińskie często opatrywano uczonymi komentarzami, w których zawierano cytaty z dzieł teologicznych. Czerpano je często nie bezpośrednio ze źródeł, ale z wszelkiego rodzaju kompendiów i antologii. Jednym z popularniejszych łacińskich dzieł o charakterze encyklopedycznym w czasach Radlińskiego była Polyanthea Sacra, autorstwa Andreasa Spannera, księga zbierająca pod różnymi nagłówkami cytaty z Biblii i komentatorów Pisma Swiętego. Okazuje się, że również autor Gemmae Sacrosanctae Crucis uległ ówczesnej praktyce literackiej i sięgnął do tej encyklopedii. Otóż jedną z części swego dzieła Spanner poświęcił Krzyżowi („Titulus XLIII. Crux”). Znajdujemy w niej podtytuł „Baculus Jacob.”, a poniżej cytat z Księgi Rodzaju oraz fragment z oracji De Exaltatione Sanctae Crucis św. Andrzeja z Krety. Zapis w Polyanthea Sacra przybiera następująca formę: „In baculo meo transivis Jordanem. Gen. 32,10. Crucis typus fuit Patriarchae Jacob virga, cum transivit Jordanem. Andreas Cret. Or. I de exalt. S. Cruc." ${ }^{17}$ Jeśli porównamy ten ustęp z komentarzem Radlińskiego znajdującym się na stronie 14 Gemmae Sancti Crucis, to okaże się, że zapis jest niemal identyczny, a tym samym staje się oczywiste, że Radliński korzystał z dzieła Spannera.

Do inwencji Radlińskiego należy natomiast umiejętne połączenie znanych symboli religijnych z własnym komentarzem poetyckim. Łatwość tworzenia łacińskich dystychów oraz umiejętność celnego pointowania myśli, zgodnie z konwencją gatunku epigramatycznego, dowodzą niejakiego talentu. Wspomniany epigramat poprzedzony lemmą „Baculus Jacob.” i umieszczony na stronie 15 Radliński kończy następującą pointą:

"Et nos si volumus barathri superare furores,

In baculo Sanctae bella gerenda Crucis"18.

Gemmae Sacrosanctae Crucis Jakuba Pawła Radlińskiego to utwór o wymowie religijnej, dostosowanej w swej formie do upodobań ówczesnego odbiorcy. Całość wraz z cyklem Bujdeckiego składa się z bez mała 150 krótkich

Dlaczego nie posłużył się słowami mówców i mową niewiązaną?

Luźnym stylem retorycznym?

Krzyż był kiedyś związany z Chrystusem, a Chrystus z Krzyżem.

Czyż nie należy mówić o krzyżu mową wiązaną?", tłum. własne.

${ }^{17}$ A. Spanner, Polyanthea Sacra: Ex universae Sacrae Scripturae Utriusque Testamenti figuris, symbolis, testimoniis... collecta, I, Venetiis 1741, 408.

${ }^{18}$ „I my jeśli chcemy pokonać szał piekielny, musimy toczyć wojny w imię łaski Świętego Krzyża”, tłum. własne. 
wierszy należących do niezwykle popularnego w dobie nowożytnej gatunku epigramatycznego. Epigramat często stanowił część kompozycji emblematycznej, na którą oprócz wiersza składało się motto (lemma) oraz obraz (pictura). Podobieństwo utworów Radlińskiego, zwłaszcza tych zamieszczonych w części pierwszej i nazwanych figurae, do kompozycji słowno-obrazowych, nie wydaje się przypadkowe. Nawiązując do tradycyjnej symboliki związanej ze świętym Krzyżem, autor celowo odwołuje się do dobrze znanych źródeł ikonograficznych, w których wykorzystywane były wspominane przez niego symbole. Podobny charakter mają utwory zawarte $\mathrm{w}$ wymienionym na początku innym zbiorze tego samego autora, a mianowicie w książce Corona urbis et orbis. Znajdują się tam wiersze nawiązujące do popularnych motywów ikonograficznych takich, jak planety, żywioły, pory dnia, kamienie szlachetne, kwiaty. Natomiast zawarte w Gemmae Sacrosanctae Crucis epigramaty związane są nie z natura, ale z symbolami biblijnymi. Tym samym udało się Jakubowi Pawłowi Radlińskiemu w dziele o Świętym Krzyżu pokazać, jak ważną rolę w pośrednictwie między Bogiem a człowiekiem odgrywa symbol.

\section{RELIGIOUS POETRY IN THE MONASTIC CIRCLE \\ OF THE ORDER OF THE HOLY SEPULCHRE IN POLAND \\ - GEMMAE SACROSANCTAE CRUCIS BY JAKUB PAWEŁ RADLIŃSKI}

\section{(Summary)}

Jakub Paweł Radliński was a General of the Order of the Holy Sepulchre in Miechow between 1744-1765. In 1755 he published in Krakow a religious book Gemmae Sacrosanctae Crucis Nostri Domini Jesu Christi (Jewels of the Sacred Cross of Our Lord Jesus Christ). It is a collection of nearly 150 Latin epigrams preceded by lemmas. The work consists of two parts. In the first section the author develops themes and symbols (figurae) drawn from Scripture, both from the Old, and from the New Testament. The second part contains predictions (prophetiae) on St. Cross. The poems are related to emblems, which were popular in the first half of the eighteenth century. Radliński's Latin book is worth reminding because of its religious and literary values. poetry.

Key words: The Order of the Holy Sepulchre, Jakub Radliński, Latin religious

Słowa kluczowe: Bożogrobcy, Jakub Radliński, łacińska poezja religijna.

\section{BIBLIOGRAFIA}

\section{Źródła}

Biblia w przekładzie księdza Jakuba Wujka z 1599 roku. Transkrypcja typu „B” oryginalnego tekstu z XVI w. i wstępy ks. J. Frankowski, Warszawa 1999. 
Fundamenta Scientiarum, Seu Principia et Axiomata, partim Philosophica, partim Theologica / suis explicationibus a M. Jacobo Paulo Radlinski [...] illustrata, Cracoviae 1753, Typis Michaelis Dyaszewski.

Gemmae Sacrosanctae Crucis Domini Nostri Jesu Christi ex [...] Sacrae Scripturae mari collectae. Seu figurae et prophetiae [...] ex libris Veteris et Novi Testamenti desumptae. Sermone ligato descriptae per [...] Jacobum Paulum Radliński [...] ordinis Canonicorum Regularium [...], Cracoviae 1755,Typis Michaelis Dyaszewski.

Polyanthea sacra: ex universae Sacrae Scripturae utriusque Testamenti figuris, symbolis, testimoniis necnon e selectis Patrum, aliorumque authorum ... collecta / labore et studio R.P. Andreae Spanner, Tomus primus, Venetiis 1741, ex Typographia Balleoniana.

\section{Opracowania}

CzARSKI B., Lemmata $w$ staropolskich konstrukcjach stemmatycznych jako przejaw hybrydyzacji gatunkowej, „Terminus” 14 (2012) 157-178.

CzArski B., Stemmaty w staropolskich ksiażkach, czyli rzecz o poezji heraldycznej, Warszawa 2012.

Estreicher K., Bibliografia polska, t. 26, Kraków 1915, 32-33

KozŁowski J., Radliński Jakub Pawet, PSB XXIX 708.

MilewsKa-WaźBińsKa B., „Corona urbis et orbis” Jakuba Pawła Radlińskiego. Uwagi o poetyckim pomniku wystawionym Bibliotece Zatuskich, „Rocznik Biblioteki Narodowej" 33-34 (2001) 57-66.

PĘCKOWski Z., Bożogrobcy w Polsce, EK II 879-881.

SkrZYNIARz R., Radliński Jakub Pawet, EK XVI 1092-1093. 